\title{
Television as Popular Culture Media and Parental Attention and Their Correlation to the Students’ Motivation
}

\section{to Choose Major}

\author{
Sudiran \\ University of Muhammadiyah Malang, Malang, Indonesia
}

\begin{abstract}
Television as one of the popular culture media plays an important role in the development of students' personality and knowledge because it provides countless information and entertainment that can enhance their knowledge as the viewers. This study was conducted to give an idea whether television viewing and parental attention can assist students to take a decision of choosing major at the senior high school. This study used descriptive method which analyzed the correlation among television viewing, parental attention, and the students' motivation to choose a major. The sample of this study consisted of 100 students of the state senior high school in Malang, East Java. The finding shows that there is no correlation among television viewing, parental attention, and the students' motivation to choose major at the senior high school. In other words, the possibility of choosing the major can be attributed to some other factors such as interest, talent, aspiration, and other expectation to achieve their goals.
\end{abstract}

Keywords: television, popular culture, media, parental attention, students, motivation

\section{Introduction}

Television can be regarded as one of the popular culture media that is used by teachers in teaching and learning process (Bruce \& Ewing, 2009). It gives considerable influence to the development of youths' personality and knowledge because it provides information and entertainment that can enhance teenagers' knowledge as the viewers. Moreover, the information is packaged in an attractive entertainment display. Judging from the impacts of television on adolescent behavior, Wilson (1995) argues that the dominance of television as a household activity often reduces the level of communication among family members. Therefore, culture is absorbed by the more teenagers coming from television than from parents.

Similarly, Rubin (2012) claimed that the media like television is truly one of the greatest and most influential teachers. It means that television is able to provide students or viewers with much information which enable them to improve their knowledge. Likewise, Comstock, Chaffee, Katzman, McCombs, and Roberts (1978) argues that television has a number of ways that can affect the viewers' experiences. These effects include audience's behavior during television viewing and the effects on other activities. Thus, television becomes popular culture media which bring great impact on the senior high school students' learning achievement.

Sudiran, Dr. (Doktor) and M. Hum. (Magister Humaniora), English Department, University of Muhammadiyah Malang. 
Furthermore, if the television can influence teenagers' behavior, it is expected that television can also contribute the same thing to motivate students to choose major at the senior high school. This is due to a significant increase in the number of private television stations in Indonesia that broadcast a variety of fascinating entertainment such as soap operas, quiz, sporting events, and other captivating shows. The importance of television in improving students' knowledge is examined by Gill (2012) who quotes UNESCO statement that empowerment of young people through information and media literacy is an important prerequisite for fostering equitable access to information and knowledge, and building inclusive knowledge societies. Moreover, all the entertainment programs are packaged in such a way that it makes viewers spend more time at home. Indonesian people especially teenagers tend to use television as a means of obtaining information and entertainment. Even many young people use television as a reference for buying certain products that they need.

In the lives of adolescents, especially the senior high school students, parents play an important role in providing their children with the advice to help them achieve their goals. Wise parents pay attention to the intellectual development of their children. Not only do parents provide their children with basic necessities such as food and clothing, but they also need to notice their children's intellectual development. Parents' attention is needed by children as the senior high school students to be successful learners. As Hoffmann and Dufur (2008) said, without attention and interaction with children, parents cannot recognize their children's characteristics and interest on which their academic achievement are based. Moreover, without parental concern, students' lives will be affected by things that are less conducive to promote their learning outcomes. Hence, the parents' attention can encourage students to improve their academic achievement.

According to Bainar (1997), parents who are just thinking about their children's physical needs are something very wrong. In the current era of globalization, which is marked by the advance of information and communications technology, providing children with the only physical and material needs are not enough. They should give more time to their children to devote their affections, and provide education in a harmonious and communicative atmosphere. Such an atmosphere will create a meaningful relationship between both children and parents.

Parental attention and supervision can be considered strategic aspects which enable parents to help their children improve their learning achievement. Parents' concern can motivate their children to learn enthusiastically. Those who pay attentions to the development of their children's intellectual are able to encourage their children to increase academic performance. The children are not going to do things that harm themselves or ignore their duty because they realize that their parents will eventually know what they did. With this kind of behavior control, then the children will always be conscious that they are supervised by their parents so that they will focus their attention on improving their academic achievement.

In the academic life, motivation is very important which enables students to be successful learners. It encourages them to do positive things in order to improve their school performance. According to Anwar (2004), motivation is categorized into two: (1) intrinsic motivation, arising from any individual such as needs, talents, interests, wishes, and expectations existed in a person, and (2) extrinsic motivation, arising from outside the individual that arise because of the stimulus from the outside environment. 
Motivation is the one's impulse caused by a particular stimulus which is considered as important factor in teaching and learning process. A senior high school student who has a dominant intrinsic motivation need not wait for the command of parents or teachers to learn the one or more subjects. He will learn it because he feels that learning is a prime activity to increase his knowledge. In other words, motivation enables students to feel enthusiastic to study from which they are capable of improving their learning achievement.

This study was conducted to give an idea whether television viewing and parental attention can assist students to take a decision of choosing program of study in a senior high school. So far, most parents consider that the television has a negative effect on teenagers. The negative impact of the television displays for teens have been published in several media at the end of 2006 in Indonesia. For example, Kompas (2006) reported that after the Indonesian Broadcasting Commission (KPI) followed up the people’s complaints. On November 29, 2006, it ruled and forbad airtime of Smack Down on the private television stations. As has been known, Smack Down show was an action scene that contained elements of violence and brute force which many teenagers liked it very much. Consequently, many students imitated the scene and hurt many other students as victims at schools.

This research is very important to carry out because it would investigate the relationship between frequency of the television viewing and parental concern with the students' motivation to choose a major at the senior high school. The results of this study will provide parents and educators with information about the role of television as one of the popular culture media in the teaching and learning process. In contrast, if the research is not conducted, public will always assume that television broadcasting brings about bad impact for teenagers, school students in particular. As a result, many parents forbid their children to view television. This can harm the people themselves because they will lack information which is available on television.

This study was guided by the following research questions:

(1) How is the correlation of television viewing and the students' motivation to choose major at the senior high school?

(2) How is the correlation of parental attention and the students' motivation to choose major at the senior highs school?

\section{Television as the Popular Culture Media}

Television is the electronic media which featured two major dimensions in the teaching and learning activities, vivid images that can move and sound. It plays a significant role in the education as teaching media that can simultaneously be seen and heard. It brings the actual and commented events which are taking place at the far away locations. An event that happens is directly transmitted from television station to the viewers' home. Both images and sound dimensions come simultaneously to the audiences. This process of conveying information causes television to become effective teaching media at schools because it provides the students with information and entertainment which increase their knowledge. As Busy Teacher (2013) reported, one of the best ways to educate students across all skills is via the means of television. It is due to television programs also provide students with realistic conversation and dialogues, which aid listening skills by offering a diverse range of accents for the students to hear. Another advantage is that the majority of TV programs use relatively simple language; otherwise they provide the viewers with a clear explanation. 
In general, it is known that television provides a great social impact on society, teenagers in particular. This influence can be seen in their everyday behavior and conversation. It means that the influence of television in the teenagers' lives will be seen in the style of their speech, their vocabulary, and social insight. Even the influence can also be seen in the form of ways to enjoy entertainment, such as watching television with a discussion or debate with other viewers. Rubin (2012) argues that people are constantly bombarded by messages (some more subtle than others) about how one should look, dress, think, feel, and act; these messages are then internalized as truth.

Many education experts explain their views on the function and influence of television in education environments. Sadiman (1996) discusses television in terms of its function. Television is a medium that conveys the audio-visual learning message. Based on its ability to reach many people as the viewers, television can be categorized into the mass media. As an educational medium, television has important characteristics such as immediate and real. Through television, students know current issues from which they can increase their knowledge. The increase in knowledge helps them improve their learning achievement at school.

Suparno, Rohadi, Sukadi, and Kartono (2002) state that television show can be brought into the classroom as a material for the study such as observation, discussion, knowledge development, and reflection. The information obtained can be used as learning materials from which the students learned many things about social lives.

In a research, Uchikoshi (2005) has proven the positive impact of television on kindergarten pupils' narrative ability. Uchikoshi studied television series "Arthur" which had characteristics such as language use, syntactic complexity, and lexical repetition all of which contributed to the positive impact of television on children's narrative ability in the kindergarten.

The role of television in raising academic achievement has also been investigated by Joireman and Abbott (2003), they take the television program into the students' activity variables along with homework and extracurricular activities, which in turn correlated with reading ability and math achievement. Based on the hypothesis testing, it is proved that television together with homework and extracurricular activities have a positive correlation to the capability of reading performance and math achievement.

Based on the results of the studies above, it can be said that television has a positive impact on increasing students' ability both language skills and mathematical ability. However, the positive impact of television needs to be studied and developed continuously because not all television programs have a positive impact on viewers. This study will explore further the impact of television on viewers' academic achievement by involving other more significant variables.

Based on the description above, it can be said that the television has a significant function for the intellectual development and the adolescents' behavior. It provides teenagers with a fresh and attractive entertainment. In terms of fashion, hair styles, and the way of conversation, teenagers often take the television superstars as role model to change their personal style. Therefore, television as popular culture product and as a part of the electronic media has contributed to influence the development of mental and physical behavior of young people. 


\section{Parental Attention}

According to Hayes (2012), parental involvement or attention has consistently been associated with school success in a multitude of areas such as better achievement and behavior, lower absenteeism, and more positive attitudes toward school. In other words, parents play a crucial role in the academic achievement of their children. People assume that the attention given to their children can affect their behavior in both inside and outside school. Even many senior high school students who won brilliant achievements at school are because of getting enough attention from their parents. Meanwhile, a lot of juvenile delinquency such as students brawl, drug abuse, promiscuities, and many other bad tempers are the impact of the lack of parental attention to their children. Therefore, the parental attention is one of the essential elements for the students to promote their academic achievement at school.

Banerjee, Harrell, and Johnson (2011) claim that parental involvement in education is associated with positive gains in children's academic and cognitive outcomes. The United States Department of Education concludes that children who have highly involved parents have better academic outcomes in elementary and secondary school. Involvement in educational activities can include enriching the home environment by helping children plan time for homework or checking homework assignments. Involvement in educational activities also can include direct school contact such as attending school functions or parent-teacher conferences. In other words, not only is parental attention to provide children with food and clothing, but it also includes education which enable the children to develop their intellectual achievement. At least, there are 12 activities as the realization of parental attention as follows:

(1) accompanying the children watching television;

(2) suggesting the children about some types of television program which are allowed to be watched;

(3) attending school conference with teachers;

(4) trying to take the children to school;

(5) trying to take the children home from school;

(6) giving the children money and punctual payment of the school tuition;

(7) monitoring the children's note book;

(8) monitoring the children's school progress;

(9) providing the children with appropriate school utensils such as bags, note books, pens, and other writing utensils;

(10) preparing the children clothing such as school uniform and shoes;

(11) motivating the children to improve their academic achievement;

(12) rewarding the children for their efforts to achieve excellent marks or progress.

Meanwhile, Suparno et al. (2002) argue that the failure of parents to detect the conflict could harm students. Students can easily fall into bad influence of mass media in their lives. In this case, teachers and parents need to learn and understand what happen to the students' life. Family values which are maintained and developed are important to solve the conflict. Combining the family values and the students' mind should be the basis for communication with parents to minimize the harmful effects caused by the mass media. In order to fulfill the students' needs, teachers and parents need to take roles as protectors, lovers, even as role models for students. 
From the above description, it can be said that apart from paying attention to their children, parents have the primary function to develop their children's knowledge and skills in order that they improve their learning achievement. The functions of parents in family life that support children's academic achievement are as patron, protector, lover, and as a role model of their children.

Purwanto (1997) states that parents play a decisive role in the intellectual development of their children. They have at leas 12 roles for their children as follows: (1) affection givers, (2) nurture, (3) problem solving, (4) regulating domestic life, (5) mentor of personal relationships, (6) family educator, (7) source of authority within the household, (8) family communicator, (9) family security, (10) family protector, (11) discipline keeper, and (12) role model.

\section{Motivation}

Senior high school students who have a lot of remarkable achievements are assumed that they possessed not only interest and talent, but they also have high motivation to master their subjects. Possessing high learning motivation, students feel enthusiastic to increase their knowledge. However, students who are not motivated in school may have low willingness to achieve success. They are reluctant to learn at school because they have no encouragement to do their school tasks. Consequently, the students who are not motivated will have lower academic performance.

According to Hamalik (1992), motivation can be defined as all of the symptoms contained stimulatory action toward a specific purpose where previously there was no movement towards that goal. Motivation can be either internal or external impulses of an individual which cause him to achieve his goals. As an integral part of the learning activities in the classroom, motivation is the process of generating, maintaining, and controlling interests and talents from which students are enthusiastic to study in order that they improve their learning performance. Similarly, McDonald (as cited in Hamalik, 1992) defines motivation as an energy change within the person characterized by affective arousal and anticipatory goal reactions. In other words, motivation is a kind of psychological power which enables individual to do important things to enhance his social life.

Moreover, motivation is individual efforts to do something. A child studies earnestly because he wants to pass the exam. In this case, passing the exam can be regarded as condition from which he studies very hard. The condition that causes a child to do something is called motivation. A remarkable learning achievement can be obtained with strong motivation. Therefore, it is very important for a teacher to raise his students' motivation in order to improve their learning outcomes (Nasution, 2000).

For the purpose of this study, motivation is defined as individual feelings or emotions that reflect his psychological tension or emotional atmosphere. This emotional atmosphere is able to create individual pattern of behavior on which individual reasons for doing something is based. Changes in the atmosphere of this emotion can be observed through a person's behavior. A person, for example, involves in a discussion because he is interested in the topic being discussed. As a result, he takes part in the discussion with enthusiasm and asking a question. In this study, it is assumed that senior high school students choose program of study because they are motivated to reach great learning achievements.

In the aspect of education, motivation is required to develop students' pattern of behavior in order that they learn their study enthusiastically. Education is the efforts prepared by teachers with a well-designed to provide 
students with appropriate learning material. Teachers need to strengthen the students' motivation in order that they are willing to learn. In the teaching and learning process, teachers are expected to increase their students' motivation either intrinsic or extrinsic which enables them to study earnestly. When the students learn their subjects with both strong intrinsic and extrinsic motivations, their possibility of improving learning outcomes is bigger than those who learn without motivations. Therefore, the motivation is needed in teaching and learning activities at schools to promote students' academic achievement. Teachers who are able to motivate their students will be capable of strengthening their students' motivation to achieve their goals, to be successful learners.

\section{Majors at Senior High School}

Mulyasa (2003) remarks that the curriculum of senior high school comprises two structures: (1) curriculum with specified major, and (2) curriculum without specification. Implementation of the specified major at the senior high school is intended to provide students with the possibility of choosing it specifically. The majors at the senior high school are natural sciences, social sciences, and language sciences. The choosing of the majors starts from grade XI because at grade X all students take all subjects, and there are no majors at this grade. Therefore, all subjects which are offered by schools at this grade are general courses that students must take all of them.

Students have their own reasons for choosing one of the three majors. Their reasons for choosing one of them are associated with their learning motivation as well as aspiration when they graduated from school. Those who aspire to be professional writers are going to take language sciences major as their main interest. This study tries to describe the students' reasons for choosing the major, and how the process of choosing the major is determined. Students' social lives are able to contribute to their decision to choose the major. Apart from social lives, mass media such as television can affect students' consideration choosing major at school.

\section{Research Method}

This study used descriptive method which analyzed the correlation among television viewing, parental attention, and the students' motivation to choose a major at the senior high school. The sample of this study is 100 students of the State Senior High School 3 Malang, East Java. There are three variables examined: (1) the frequency of television viewing, (2) parental attention, and (3) students' motivation to choose major at the senior high school. To get the data, this study applied questionnaire which consisted of 45 items and comprised of three options each. The questionnaire was classified into three sections: (1) comprising of 15 items to collect the data about the frequency of students viewing television, (2) of 16 items to collect the data of the parental attention, and (3) of 14 items to collect the data of the students' motivation to choose major at school.

\section{Data Analysis}

The data obtained from the questionnaire was analyzed by using SPSS 10 program. The scores of the questionnaire were the total number of options given by the respondents. The values obtained from the data analysis were used to test the hypothesis formulated as follows:

(1) HO: "There is no a significant correlation between television viewing, parental attention and the students' motivation to choose major at school.” The acceptance of Ho must fulfill the following criteria: $r<r_{\text {tab }}$ 
for significant of $\mathrm{p}>0.05$.

(2) HA: "There is a significant correlation between television viewing, parental attention and the students' motivation to choose major at school." The acceptance of HA must fulfill the following criteria: $r>r_{\text {tab }}$ for significant of $\mathrm{p}<0.05$.

The result of the computation of the hypothesis test was used to interpret the research findings.

\section{Validity Test}

This study examined validity of the research instrument used. From the computation of the validity test of the questionnaire it was found that (1) there were 13 items of the frequency of television viewing were valid with correlation coefficient $=0.369-0.567$, for significant of $p<0.05$; (2) there were 14 items of the parental attention were valid with correlation coefficient $=0.386-0.715$, for significant of $\mathrm{p}<0.05$; and (3) the computation of the validity of the students' motivation to choose major was 11 items which were valid with correlation coefficient $=$ 0.356-0.467 for significant of $\mathrm{p}<0.05$. For this reason, it could be said that the questionnaire as research instrument was valid.

\section{Findings}

Based on the result of the data computation, it was found that the values of hypothesis test showed:

(1) The value of the correlation between the frequency of television viewing and the students' motivation to choose major was $r=0.075$, and the value of $r_{\text {tab }}=0.195$, and $p=0.605$ or $p>0.05$. It meant that the value of $r=$ $0.075<\mathrm{r}_{\mathrm{tab}}=0.195$ and $\mathrm{p}=0.605$ or $\mathrm{p}>0.05$. For this reason, Ho was accepted which meant no correlation between the frequency of television viewing and the students' motivation to choose major.

(2) The value of the correlation between parental attention and the students' motivation to choose major was $\mathrm{r}=0.184$ and $\mathrm{r}_{\mathrm{tab}}=0.195$, and the value of $\mathrm{p}$ equaled to 0.201 or $\mathrm{p}>0.05$. It meant that the value of $\mathrm{r}$ was equal to $0.184<\mathrm{r}_{\text {tab }}=0.195$ and $\mathrm{p}=0.201$ or $\mathrm{p}>0.05$. Accordingly, Ho was accepted which meant no correlation between the parental attention and the students' motivation to choose major at the senior high school.

From the value of the hypothesis test above, it can be explained that the frequency of television viewing has not affected the students' motivation to choose the major at school. Similarly, the students' motivation to choose the major at the senior high school has not been influenced by their parental attention. In other words, motivation or reason for choosing major is not associated with both the frequency of television viewing and parental attention. However, the possibility of choosing the major can be attributed to some other factors such as interest, talent, aspiration, and other expectation to achieve their goals.

\section{Discussion}

Noticing the value of hypothesis test, no correlation between the independent variables is accepted. The research independent variables examined are the frequency of television watching and the parental attention. Moreover, the research dependent variable is the students' motivation to choose major at the senior high school. In other words, there is no correlation between watching television and the students' motivation to choose major at school. In the same fashion, there is no correlation between parental attention and the students' motivation to choose major. 
Based on the findings, it can be said that other dominant factors exist in the students' motivation to choose major at the senior high school. Those dominant factors should be examined to reveal the correlation between television viewing and the motivation to select major. The consideration to examine the correlation between television viewing and the students' motivation is that television can be regarded as integral part of popular culture media which offers meaningful information from which the students as viewers are able to improve their knowledge. Motivation in education plays a significant role in the students' academic achievement. Therefore, teachers are expected to strengthen the students' motivation because knowing their motivation can help them develop their students' learning outcomes.

There are three possibilities of why null hypothesis is accepted which means no correlation between television viewing and the students' motivation to choose major at school. Firstly, the research population of this study is grade XI students of the State Senior High School 3 Malang. According to one of the English teachers of the school, $80 \%$ of the students take natural sciences major, and the rest of the $20 \%$ take social sciences major. It means that the head master of the school has considered the natural sciences to be the excellent major.

Secondly, other possibility of accepting the null hypothesis is that the population of this study is one school which emphasizes natural sciences major. The students who major in natural sciences have different learning habit from those other major. They give more priority to read some textbooks than to watch television. The last, other reason for accepting the null hypothesis is that this study consists of 100 students of grade XI as sample from which of 80 students are natural sciences and of 20 are social sciences major. Accordingly, the possibility of the students who major in natural sciences has less frequency of television viewing than those who major in other natural sciences. Moreover, the natural sciences students have so strong intrinsic motivation that they do not need external factor to increase their learning achievement. They prefer reading and learning to wasting the time for viewing television. Therefore, this research needs to be developed by adding more samples from many schools in order to strengthen the possibility of accepting the alternative hypothesis which proves that there is a significant correlation between television viewing and the students' motivation to choose major at schools.

\section{Conclusion}

Based on the data analysis above, it can be concluded that: (1) The students' motivation to choose major at the senior high school is not strongly affected by the frequency of television viewing; (2) the parents' attention has no influence on the students' motivation to choose major at school. It is assumed that other dominant variables such as interest, career aspirations, and desire to continue study have strongly influenced the students' motivation to choose major at the senior high school.

There are three strong possibilities of why null hypothesis is accepted which meant that there is no relationship among television viewing, parental attention, and students' motivation to choose major at school, namely: (1) $80 \%$ of the students take natural sciences major, and the rest of the $20 \%$ take social-sciences major. It means that most students have no time to watch television because they have different learning style to other students with other major. Natural sciences major demands students' concentration on their subjects; (2) the population of this study is one school in which the total number of students who choose natural sciences major is bigger than other majors. This fact causes most students negatively to respond to questionnaire which correlated the television viewing and their motivation to choose major; (3) the sample of this study consists of 80 students of 
natural sciences and of 20 students of social sciences major. Accordingly, the possibility of the students who major in natural sciences has less frequency of television viewing than those who major in social sciences.

\section{References}

Anwar. (2004). Pendidikan Kecakapan Hidup (Life skills education). Bandung: Alfabeta.

Bainar. (1997). Generasi Pembuka Jendela Dunia (Future generation). Jakarta: IPPSDM-WIN.

Banerjee, M. Z., Harrell, A. T., \& Johnson, D. J. (2011). Racial/ethnic socialization and parental involvement in education as predictors of cognitive ability and achievement in African American children. Journal Youth Adolescence, 40, 595-605.

Bruce, J. A., \& Ewing, J. C. (2009). Popular culture media as a teaching tool in agricultural and extension education. NACTA Journal, 53(4), 8-11.

Busy Teacher. (2013). How to use TV in your classroom: 6 creative ESL approaches. Retrieved from http://busyteacher.org/5648use-tv-in-classroom-6-esl-approaches.html

Comstock, G., Chaffee, S., Katzman, N., McCombs, M., \& Roberts, D. (1978). Television and human behavior. New York: Columbia University Press.

Gill, R. (2012). Media, empowerment and the "sexualization of culture” debates. Feminist Forum, 66, 736-745.

Hamalik, O. (1992). Psikologi Belajar dan Mengajar (Psychology for teaching and learning). Bandung: Sinar Baru.

Hayes, D. (2012). Parental involvement and achievement outcomes in African American adolescents. Journal of Comparative Family Studies, 43(4), 567-XI.

Hoffmann, J. P., \& Dufur, M. J. (2008). Family and school capital effects on delinquency: Substitutes or complements? Sociological Perspectives, 51(1), 29-62.

Joireman, J., \& Abbott, M. (2003). Structural equation models assesing relationships among students activities, ethnicities, poverty, parents's education, and academic achievement. WSRC: Seattle Pacific University.

Mulyasa, E. (2003). Kurikulum Berbasis Kompetensi: Konsep, Karakteristik, dan Implementasi (Competence-based curriculum: Concept, characteristics, and implementation). Bandung: P.T. Remaja Rosdakarya Bandung.

Nasution. (2000). Didaktik Asas-asas Mengajar (Didactic: The principle of teaching). Jakarta: Bumi Aksara.

Purwanto, N. (1997). Ilmu Pendidikan Teoretis dan Praktis (Science of education: Theory and practice). Bandung: PT Remaja Rosdakarya.

Rubin, D. I. (2012). Critical pedagogy and dialectical thought in the secondary English classroom. Theory in Action, 5(2), 70-81.

Sadiman, A. S. D. (1996). Media Pendidikan: Pengertian, Pengembangan dan Pemanfaatannya (Teaching media: Definition, development and application). Jakarta: PT. RajaGrafindo Persada.

Smack Down, Masyarakat Menggunakan Haknya (Smack down, people implemented their rights). (2006, December 6). Kompas, 2.

Sudijono, A. (1992). Pengantar Statistik Pendidikan (Statistics for education: Introduction). Jakarta: Rajawali Pers.

Suparno, P., Rohadi, R., Sukadi, G., \& Kartono, S. T. (2002). Reformasi Pendidikan Sebuah Rekomendasi (Educational reform: A recommendation). Yogyakarta: Kanisius.

Uchikoshi, Y. (2005). Narative development in bilingual kindergarteners: Can arthur help? American Psychology Association, 41(3), 464-478.

Wilson, S. L. R. (1995). Mass media? Mass culture: An introduction (3rd ed.). New York: McGraw-Hill, Inc.. 